\title{
Nacionalinis saugumas ir tarptautinès politikos iššūkiai pasaulyje po Stuxnet atsiradimo
}

\begin{abstract}
Tarptautinè bendruomenè skiria daug dèmesio nusikalstamumui ir socialinio-politinio pobūdžio incidentams kibernetinèje erdveje. Deja, ị ịtariamụjų, atsakingų už kibernetinèje erdvẻje vykdomus įsilaužimus, susietus su intelektualinès nuosavybès, asmeninių duomenų, pinigų pasisavinimo atakomis ir tinklo paslaugų žlugdymu, sąrašą papuola ne tik dèmesio siekiantys studentai programišiai, kibernetiniai nusikaltèliai ar socialinès-politinès pakraipos programišiai, bet ir vyriausybès. $2010 \mathrm{~m}$. birželio mèn. pasirodžius kenkejiškai Stuxnet tipo programinei ịrangai, sukurtai naikinti specialiai numatytus ypatingos svarbos infrastruktūros komponentus, buvo bene pirmasis požymis, kad kai kurios valstybės ėmèsi piktavališkos veiklos kibernetinëje erdvèje. Aktyvaus valstybių kibernetinių atakų rengimo ir vykdymo prieš ypatingos svarbos kitų valstybių infrastruktūras problema tarptautinès bendruomenès buvo ignoruojama. Šios atakos kelia nacionalinio saugumo problemų dèl grésmių ekonominei ir socialinei valstybių gerovei. Tačiau kai visur esanti kibernetinė erdve yra kaip bendra aplinka, kur vyksta visi šiuolaikiniai pramoniniai procesai ir pletojama sąveika tarp kitų valstybių ypatingos svarbos infrastruktūrų, kibernetinio saugumo klausimai peržengia vienos valstybės ribas. Tarptautinè bendruomené privalo imtis priemonių, kurios užtikrintų, kad valstybėms naudojant ši naujaji ginklą, jis netaptų nevaldomas ir nesukeltų naujų dar rimtesnių tarptautinių konfliktų. Pateikiami trys šios problemos sprendimai ir galimas šios ardomosios valstybių veiklos kibernetinejje erdvejje valdymo tarptautiniu lygmeniu modelis.
\end{abstract}

\section{Ivadas}

Kibernetinè erdvè nematoma, bet visur esanti elektromagnetinès veiklos, paremtos informacijos ir ryšių technologijomis, sritis glaudžiai susijusi su kitomis žmogiškosios veiklos sritimis. Šioje aplinkoje išsivystė sistemos ir procesai, apimantys šiuolaikines finansų, energetikos, transporto ir telekomunikacijų sistemas, grindžiamas naujųjų dinamiškų technologijų pajėgumais. Šios sistemos išaugo ị kompleksines tarpusavyje susietas infrastruktūras ir

\footnotetext{
*Vytautas Butrimas - Lietuvos Respublikos krašto apsaugos ministerijos vyriausiasis patarejas kibernetinio saugumo klausimais. Adresas korespondencijai: Totorių g. 25/3, 01121 Vilnius, tel. (8 5) 273 5775, el. p. vytautas.butrimas@kam.lt .

** Siame straipsnyje pateikti vertinimai ir mintys yra tik autoriaus ir niekada negali būti vertinamos kaip Lietuvos Respublikos krašto apsaugos ministerijos ir jos padalinių oficiali pozicija.
} 
procesus, kurie yra ypač svarbūs šiuolaikinès visuomenės ir ekonomikos funkcionavimui.

Kartu su naujaisiais pajegumais atsirado ir nauji pažeidžiamumai. Priešiški veikejjai, išmanantys šiuos pažeidžiamumus, gali vykdyti kibernetines atakas, kurios pajègios ne tik sužlugdyti ypatingos svarbos paslaugas ar pramoninius procesus, bet ir kelti grèsmę žmonių gyvybei. Nuo to, kokiu mastu kibernetinès atakos paralyžiuoja ypatingos svarbos infrastruktūrų procesus ir paslaugas, priklauso, ar saugumo klausimai yra nacionalinio ar tarptautinio lygmens. Kibernetinè ataka prieš su finansais susijusio objekto telekomunikacijų ir informacinę infrastruktūrą gali sukelti didelę visuomenès įtampą ar net vyriausybès krizę. Isivaizduokite, kad žmonès visą savaitę negali naudotis savo kredito kortelèmis arba neturi galimybès atlikti kitų elektroninių sandorių. Kiek laiko mes galètume gyventi naudodami tik grynuosius pinigus, jei prekybos centrai ir degalinès staiga priimtų mokejjimus tik grynaisiais (kaip Kipre, kai vyriausybè įsakè uždaryti bankus 2013 m. pavasarị)? Pagalvokite apie tai, kas nutiktų, jei atominès elektrinès, naftotiekio ir (ar) geležinkelio kontrolès centro operatoriai staiga nebematytų vaizdo ir netektų galimybės valdyti nepaprastai svarbaus proceso? Tai pasaulyje jau yra nutikę ir sukèlè didžiulių nuostolių ir pareikalavo žmonių gyvybių.

Per pastaruosius 10 metų piktavališkos kibernetinès veiklos ir grėsmių šaltiniai buvo kibernetiniai nusikalteliai ir kompiuterių programišiai - socialinės-politinès pakraipos programišiai. Dažniausiai, tvarkymasis su tokiais piktavališkais kibernetinès erdvès veikejjais yra paliekamas teisèsaugos institucijoms. Neseniai ịvykę ir viešai nuskambèję šių individų ir mažų nusikalstamų grupuočių areštai buvo atlikti dèka suderintų vidaus ir tarptautinès teisètvarkos organų pastangų ${ }^{2}$. Tarptautinè bendruomenè labiausiai linkusi suprasti kibernetinị saugumą kaip kibernetinį nusikalstamumą arba kaip kibernetinị terorizmą. Geras pavyzdys yra Europos Sąjungos arba Budapešto konvencija dèl kibernetinių nusikaltimų ${ }^{3}$. Kitas pavyzdys yra neseniai paskelbtas ESBO vadovas, nurodantis, kaip apsaugoti ypatingos svarbos energetikos infrastruktūras

\footnotetext{
${ }^{1}$ Steininger M., „What's behind the bailout crisis in Cyprus?“, Christian Science Monitor, http://www. csmonitor.com/World/Europe/2013/0329/What-s-behind-the-bailout-crisis-in-Cyprus , 29032013. ${ }^{2}$ Gilbert D., „Dutch Suspect Sven Olaf Kamphuis Arrested for Biggest Cyber Attack in Internet History“, International Business Times, http://www.ibtimes.co.uk/articles/461848/20130426/spamhaus-suspectarrests-spain-kamphuis.htm, 26042013.

${ }^{3}$ Council of Europe, Convention on Cybercrime, http://conventions.coe.int/Treaty/en/Treaties/Html/185. htm , 23112001.
} 
nuo teroristinių grèsmių, kylančių kibernetinèje erdvejje ${ }^{4}$. ESBO pripažino, kad šios infrastruktūros „sužlugdymas ar sunaikinimas [įvykdytas teroristų] turètų rimtą poveikị saugumui, saugai, ekonominei gerovei žmonių sveikatai ir pasauliui apskritai “ ${ }^{\text {. }}$. Tačiau išlieka klausimas, ar teroristai yra vieninteliai grèsmę keliantys veikejjai, galintys panaudoti kibernetinius masinio naikinimo ginklus tam, kad paralyžiuotų arba sunaikintų ypatingos svarbos infrastruktūrą. Nèra aiškių ịrodymų, kad „Al-Qaida“ grupuotės tipo teroristai planuotų pasinaudoti kibernetine erdve savo atakoms. Jiems dar trūksta gebejjimų, susidomëjimo ir pajègumų, kad galètų patys parengti ir panaudoti kompleksinius kibernetinius ginklus. Egzistuoja dar vienas, mažai ịvertintas kibernetinių grèsmių ypatingos svarbos infrastruktūrai šaltinis piktavališka valstybių veikla.

Per praejusị dešimtmetị piktavališka valstybių veikla kibernetinejje erdveje virto problema, kurią reikia įtraukti ị tarptautinio saugumo politikos dienotvarkę. Kibernetinès atakos jau peržengè patriotinių ar politiškai motyvuotų kibernetinių riaušių, pasibaigusių laikinomis paslaugų blokavimo atakomis, nukreiptomis prieš Estijos vyriausybę, bankų ir žiniasklaidos portalus 2007 m., ribas. Nuo tada jos pakito: imta naudoti kibernetinius ginklus, galinčius sunaikinti ypatingos svarbos infrastruktūras. Tokiais pavyzdžiais gali būti laikoms kibernetinès atakos, prasidejusios 2009 m. prieš Irano branduolinius objektus, $2012 \mathrm{~m}$. Saudo Arabijos naftos pramonę ir $2012 \mathrm{~m}$. pabaigoje ir 2013 m. pradžioje prieš finansines Jungtinių Amerikos Valstijų institucijas.

Nesièmus tarptautinių veiksmų, nukentẻjusių valstybių reakcija į šias atakas vedè prie kibernetinès ginkluotès varžybų pradžios ir netgi prie grasinimų atsakomuoju smūgiú. Tarptautinès institucijos, kurių užduotis yra skatinti taiką ir tarptautinę tvarką, nepasiekẻ sutarimo, kokių veiksmų imtis šiuo atveju. Tačiau problema ir toliau neišnyks, kadangi kibernetinès atakos, nukreiptos prieš ypatingos svarbos infrastruktūras, turi didelị valstybių sienas peržengiantị poveikị, kuris gali destabilizuoti tarptautinę padètị. Dabar valstybės supranta, kaip sunku nustatyti užpuoliką ir tai, kad sèkmingų paneigimų kaina yra palyginti nedidelè. Kokius naujus iššūkius ši piktavališka valstybių veikla kibernetinèje erdveje kelia formuojant tarptautinę saugumo politiką? Kuo rizikuoja tarptautinė bendruomenè nesiimdama veiksmų, kad ši problema būtų sprendžiama? Ką galima būtų padaryti siekiant išspręsti šią problemą

\footnotetext{
${ }^{4}$ Organisation for Security and Cooperation in Europe, Good Practices Guide on Non-Nuclear Critical Energy Infrastructure Protection (NNCEIP) from Terrorist Attacks Focusing on Threats Emanating from Cyberspace, http://www.osce.org/atu/103500, 2013.

${ }_{5}$ Ten pat, p.7.

${ }^{6}$ Alexander D., „US reserves right to meet cyber attack with force“, Reuters, http://www.reuters.com/article/2011/11/16/us-usa-defense-cybersecurity-idUSTRE7AF02Y20111116, 15112011.
} 
ir sumažinti galimybę kibernetinei atakai peraugti ị didesnị konfliktą? Straipsnyje bus aptartos šios problemos ir tarptautinè bendruomenè skatinama kreipti daugiau dèmesio ị piktavališkos valstybių kibernetinès veiklos problemas ir jas spręsti .

\section{Aplinkoje, kur nèra kibernetinès erdvès „šerifo“, valstybès tampa kibernetinès erdvès „nusikaltėlèmis“}

2007 m. piktavališka valstybių veikla atsirado kaip naujas kibernetinių grèsmių, nukreiptų prieš ypatingos svarbos infrastruktūras, šaltinis. Jau buvo daug rašyta apie $2007 \mathrm{~m}$. balandžio mèn. paslaugų blokavimo kibernetines atakas, nukreiptas prieš elektroninius Estijos vyriausybės ir bankų tinklus. Jos buvo pavadintos pirmuoju kibernetiniu $\mathrm{karu}^{7}$, galimai vykusiu vyriausybei palaikant. Nors šios paslaugų blokavimo atakos buvo laikinai sèkmingos, jos nepadarè realios ilgalaikès fizinės kompiuterinès ịrangos ar informacinių sistemų žalos. Bronzinio kario statulos incidentas buvo pakankama priežastis, susivienijusiems prorusiškiems kibernetiniams nusikaltèliams ir politiniams programišiams sukelti kibernetines riaušes. Nors buvo neįmanoma įrodyti, estai laikè savo kaimynę Rusiją atsakinga už šias atakas. Verta prisiminti, kad Estija buvo priversta atsijungti (keletui valandų) nuo interneto. Niekas nepasitarnautų potencialaus agresoriaus veiksmams prieš valstybę labiau, negu nutrauktas aukos gebejjimas bendrauti su išoriniu pasauliu.

Dar grėsmingesnè ir verta paminèti kibernetinès erdvės ataka ịvyko tụ pačių metų pabaigoje. $2007 \mathrm{~m}$. rugsèjo mèn. Izraelio oro pajègos sèkmingai issibrovè ị Sirijos oro erdvę ir bombardavo slaptą branduolinį objektą. Šis, atrodo, lengvas ịsibrovimas ị oro erdvę sukèlè kai kurių aviacijos ekspertų ịtarimų . Daugeliui kilo klausimas, kaip vienai moderniausių Artimųjų Rytų oro gynybos sistemų nepavyko užfiksuoti ir reaguoti ị rimtą savo oro erdvés pažeidimą ir savo suverenios teritorijos bombardavimą (beje, Sirijos oro gynyba vèliau neturejo jokių problemų, susekè ir numušè vieną reaktyvinị Turkijos lèktuvą, skridusị virš Viduržemio jūros $\left.{ }^{9}\right)$ ? Ekspertai išreiškè mintị, kad Izraelio kariuomenè pasinaudojo „kibernetiniu triuku“, kad sutrikdytų ar išvestų iš

\footnotetext{
${ }^{7}$ Traynor I., „Russia accused of unleashing cyberwar to disable Estonia“, The Guardian, http://www.theguardian.com/world/2007/may/17/topstories3.russia, 15052007.

${ }^{8}$ Carroll W., „Israel's Cyber Shot at Syria“, Aviation Week, http://defensetech.org/2007/11/26/israels-cybershot-at-syria, 26112007.

9 Burch J. „Pilot bodies from downed Turkish jet retrieved“, Reuters, http://www.reuters.com/article/2012/07/05/us-syria-crisis-jet-bodies-idUSBRE8640KU20120705, 05072012.
} 
rikiuotès Sirijos oro gynybą ${ }^{10}$. Richardas A. Clarke’as, buvęs JAV vyriausybès patarejas nacionalinio saugumo klausimais, manė, kad šis paaiškinimas buvo gana tikètinas, jog būtų įtrauktas ị jo knygą kaip kibernetinio karo pavyzdys ${ }^{11}$. Sumanytojų tikslas buvo akivaizdžiai pasiektas. Itartinas branduolinis objektas buvo neutralizuotas beveik be jokių pasekmių puolejjams. Kaip ir Estijos kibernetinès atakos atveju, nebuvo galima įrodyti, kad vyriausybè rèmé piktavališką kibernetinę veiklą. Išmoktas pamokas apie tokių atakų efektyvumą ir tarptautinio atsako trūkumą, žinoma, pastebejo tų atakų organizatoriai ir, galbūt, tie, kurie dar tik svarstė apie galimybę vykdyti panašias atakas.

Nors ataka prieš Sirijos karinę oro gynybos sistemą sukèlė mažai susirūpinimo, nereikia pamiršti, kad ji naudoja panašius lokatorius, kokie yra naudojami civiliniam oro eismui reguliuoti. Civilinè aviacija yra dalis transporto infrastruktūros, kurios valdymo sistemos yra pažeidžiamos kibernetinių incidentų ir atakų atveju.

2008 m. rugpjūčio mèn. kibernetinè ataka, kaip priemonė skirta laikinai sutrikdyti šalies kibernetinę erdvę, igijo naują dar baisesnę formą - imta naudoti kibernetines atakas kartu su tradicinemis karinemis operacijomis. Tokia forma apėmè keletą elementų, prieš metus panaudotų atakoje prieš Estiją: masinis patriotizmas, reikiamai nukreiptas socialinių tinklų, profesionalūs užkrèstų kompiuterinių tinklų operatoriai, organizuoto nusikalstamumo elementai ir ịtariama (bet neįrodyta) vyriausybès parama. Taip buvo įvykdyta gerai suplanuota, tinkamu laiku atlikta šali silpninanti kibernetine ataka ir prieš Gruzijos vyriausybės ir civilinių institucijų tinklus. Šios atakos metu pavyko atkirsti Gruzijos vyriausybę, jos gyventojus ir pasaulị nuo galimybès naudotis internetine informacija apie ịvykius šalyje. Trumpiau tariant, Gruzijos galimybė organizuoti ir koordinuoti savo nacionalinę gynybą buvo labai komplikuota. Vienas kibernetinès atakos prieš Gruziją tyrimas teigè, kad atsirado dar pavojingesne kryptis - galimybė fiziškai sunaikinti ypatingos svarbos infrastruktūros komponentus ${ }^{12}$. Neaišku dèl kokios priežasties, tačiau kaltininkai nutarè susilaikyti ${ }^{13}$. Nepaisant keleto areštų Gruzijoje, tarptautiné bendruomenè nesièmé jokių veiksmų, siekdama nubausti atsakingus už šias kibernetines atakas asmenis. Buvo išmokta ir ịsisąmoninta, kad piktavališki

\footnotetext{
${ }^{10}$ Fulghum D. A., „Why Syria's Air Defenses Failed to Detect Israelis“, Aviation Week, http://www.aviationweek.com/Blogs.aspx?plckBlogId=Blog:27ec4a53-dcc8-42d0-bd3a-01329aef79a7\&plckPostId=Blog:27ec 4a53-dcc8-42d0-bd3a-01329aef79a7Post:2710d024-5eda-416c-b117-ae6d649146cd , 03102007.

${ }^{11}$ Clarke R., Cyber War, Harper Collins, 2010, p. 7.

${ }^{12}$ Bumgarner J., Scott B., „Overview by the US-CCU of the Cyber Campaign Against Georgia in August of 2008.", U.S. Cyber consequences Unit., http://www.registan.net/wp-content/uploads/2009/08/US-CCUGeorgia-Cyber-Campaign-Overview.pdf , 2009, p. 5.

${ }^{13}$ Ten pat, p.5.
} 
veiksmai kibernetinėje erdvėje yra patrauklus pasirinkimas, kai niekas net nebando pričiupti ir nubausti.

\subsection{Stuxnet}

2009 m. pradžioje vis dar nebuvo neginčijamų įrodymų, kad valstybès dalyvauja rengiant ir vykdant kibernetines atakas. Taip buvo iki pat $2010 \mathrm{~m}$. vasaros, kai kibernetinio saugumo bendruomenę pasiekè pirmieji pranešimai apie sudètingą kibernetini ginklą, sukurtą atakuoti ypatingos svarbos infrastruktūras. Stuxnet kenkejjiškos kompiuterinès programos buvo netikètos daugeliui analitikų. Techniniu požiūriu, pavojingiausi Stuxnet elementai trukdè valdyti ir kontroliuoti procesus, vykstančius kompleksinèse pramoninèse sistemose ${ }^{14}$. Piktavališka šio kibernetinio ginklo programavimo sistema sukeldavo ịrangos ir su ja susijusių pramoninių procesų kontrolès praradimą ir „vaizdo išnykimą“. To buvo pasiekta perimant ir ịvedant klaidingus operatoriams siunčiamus duomenis, rodančius, kad sistemos funkcionuoja normaliai, nors iš tikrụjų buvo priešingai. Paprasčiau tariant, poveikis buvo panašus ị tai, kas nutiktų automobilio vairuotojui, kai variklio mechanizmais būtų manipuliuojama nukreipiant automobilį nuo uolos. Tokiu atveju vairuotojas nejaustų nerimo ir poreikio imtis veiksmų, kadangi kelio priekyje vaizdas, jo manymu, yra normalus. Net jei jis bandytų imtis veiksmų noredamas išsigelbèti, paaiškètų, kad jis negali kontroliuoti vairo, stabdžių pedalo ir variklio. Stuxnet yra kitoks dèl to, kad jis neatakavo „Windows" kompiuterių. Greičiau jis siekè sugadinti įrangą, naudojamą reikšminguose gamybos procesuose. Jis nebuvo ir kibernetinis nusikaltimas, nes akivaizdu, kad nebuvo pelningas. Priešingai, techninio meistriškumo lygis ir intelektualinis indèlis, reikalingas parengti ir nukreipti ši ginklą ị numatytą taikinị (urano sodrinimo gamykla Irane) rodè valstybės lygmens veiklą (norint daugiau sužinoti apie Stuxnet ir operaciją „Olympic Games“, verta perskaityti Davido E. Sangerio knygą) ${ }^{15}$.

Galima sakyti, kad Stuxnet atsiradimas yra panašus ị Hirosimos atveji, turint galvoje pakitusią mąstymo sanklodą kibernetinio saugumo ir tarptautinių santykių srityje. Pirmoji žinoma ir ịvykdyta vienos valstybės kibernetinè ataka prieš kitos valstybès ypatingos svarbos infrastruktūras parodè, kad „pirštinès nebemūvimos“. Buvo pripažinta, kad ši technologija taikoma siekiant išvesti iš rikiuotè ir sunaikinti įrenginius ir sužlugdyti pramoninius

\footnotetext{
${ }^{14}$ Langner R., „Cracking Stuxnet: a 21st century cyber weapon“, Ted Conferences, http://www.ted.com/ talks/ralph_langner_cracking_stuxnet_a_21st_century_cyberweapon.html , 032011.

${ }^{15}$ Sanger D., Confront and Conceal, Crown Publishers, New York, 2012, p. 504
} 
procesus. Ši operacija, kuri tikriausiai buvo politiškai motyvuota (neleisti Irakui pasigaminti bombos), taip pat sukūrè naują problemą, nurodančią, kad kibernetiniai ginklai gali patekti mažiau kvalifikuotiems politiniams programišiams, nusikaltèliams ir netgi teroristinèms grupuotėms ${ }^{16}$. Deja, Stuxnet kodas pateko ị internetą, kur jis gali būti laisvai kopijuojamas ir analizuojamas. Metodus galima išstudijuoti, o programinę sistemą pritaikyti, siekiant vykdyti naujas ardomąsias kibernetines atakas. Ypatingos svarbos infrastruktūra (telekomunikacijos, energetikos, finansų), kuri iš esmès iki tol gyvavo savame izoliuotame uždarų komunikacijos tinklų ir technologijų pasaulyje, tapo nauja programišių interesų sritimi. Ne vien vyriausybès gali ieškoti būdų, kaip išnaudoti naujai atsiradusius pažeidžiamumus ir padaryti fizinę žalą nacionalinių ypatingos svarbos infrastruktūrų pramonès valdymo sistemoms. Pirmą kartą buvo galima pagrịstai galvoti apie realaus kibernetinio terorizmo galimybes. Ši technologija dabar tapo prieinama teroristu grupuotems, kurioms trūko gebejimų sukurti savo kibernetinius masinio naikinimo ginklus (angl. weapon of mass destruction, WMD). Stuxnet dar kartą priverte pasimokyti iš ankstesnių kibernetinių atakų. Akivaizdi šios operacijos sèkmè ne tik prisidejjo prie reikšmingų infrastruktūrų pažeidžiamumo suvokimo, bet taip pat pateikè naują problemą tarptautinei saugumo politikos bendruomenei: ką daryti su valstybėmis, žaidžiančiomis kibernetinius žaidimus su viena kitos ypatingos svarbos infrastruktūromis? Kalbant apie ataką prieš Siriją 2007 m., Stuxnet operacijos kritika buvo nutildyta. Galbūt, kai kas galvojo, kad ji pasitarnavo naudingam tikslui sumažindama grèsmę (neleisti Iranui pagaminti bombos). Neịvertinama tai, kad dauguma potencialių Stuxnet tipo atakų taikinių, t. y. objektų, kurie yra mažiau apsaugoti (nepožeminiai) ir labiau pažeidžiami (daugiau galimybių prasiskverbti), yra ne Vidurio Rytuose, bet išsivysčiusiose šalyse Europos, Šiaurès Amerikos ir Azijos regionuose, turinčiuose ypatingos svarbos infrastruktūrų.

\section{2. „Saudi Aramco“ 2012}

2012 m. gruodžio mèn. dar vienos valstybès ypatingos svarbos infrastruktūra patyrè kibernetinę ataką. Saudo Arabijos naftos kompanija „Saudi Aramco" patyrè tikslinę kibernetinę ataką prieš savo kompiuterius. Šiam kibernetiniam ginklui, pavadintam SCHAMOON, pavyko visiškai ištrinti dau-

\footnotetext{
${ }^{16}$ Simonite T., „Stuxnet Tricks Copied by Computer Criminals“, MIT Technology Review, http://www. technologyreview.com/news/429173/stuxnet-tricks-copied-by-computer-criminals/, 19092012.
} 
giau negu 30000 kompiuterių kietųjų diskų. Atrodo, kad ši ataka apsiribojo vien kompanijos administracija ir neatakavo ypatingos svarbos infrastruktūros dalių, susijusių su naftos gamyba ir apdorojimu. Tačiau Saudo Arabijos žmonès šią kibernetinę ataką traktavo kaip grasinančią ne tik ypatingos svarbos energetikos infrastruktūrai, bet ir jų ekonomikai ${ }^{17}$. Nors ịtikinamų įrodymų nebuvo, itarimas, kad už tai atsakinga kitos vyriausybès kibernetiné jèga ${ }^{18}$, buvo stiprus. Dar kartą buvo pabrèžta, kad kibernetinès atakos yra patrauklus ir labai efektyvus įrankis, norint mažomis sąnaudomis pridaryti priešininkui žalos ir nebūti teisiškai už tai atsakingiems. Šią problemą vis labiau sunkino tai, kad atsirado požymių, jog šios atakos buvo kontrsmūgiai, surengti kaip atsakas i ankstesnes atakas ${ }^{19}$. Be to, atrodé, jog ima ryškèti tam tikras modelis. Tokie rajonai, kaip Vidurio Rytai, žinomi dẻl ilgalaikių rusenančių konfliktų, įsiliejo ¡ kibernetinę erdvę kaip nauja konflikto dimensija ir atvirkščiai. Dar vienas to pavyzdys yra kibernetinè ataka prieš Pietų Korejos vyriausybès žinių agentūras ir finansų tinklus, kuri baigėsi daugiau nei 30000 kompiuterių ir jų duomenų sunaikinimu ${ }^{20}$.

\section{Tarptautinių organizacijų reakcija i savo narių veiksmus kibernetinèje erdvèje}

Kokia buvo tarptautinės bendruomenės reakcija ị šių valstybės remiamų kibernetinių atakų panaudojimą prieš kitos valstybès ypatingos svarbos infrastruktūrą? Atsakymas: praktiškai jokios. Atsimenu dalyvavimą Interneto valdymo forumo (angl. Internet Governance Forum, IGF), turinčio Jungtinių Tautų mandatą, susitikimuose Vilniuje $2010 \mathrm{~m}$. rugsėjo mėnesị. Interneto privatumas ir prieigos laisvè buvo dominuojantys klausimai, tačiau, kaip teigè kai kurie autoriai $^{21}$, IGF ignoravo rimtesnius ịvykius kibernetinèje erdvejje, susijusius su nacionalinio saugumo klausimais ir tiesiogiai susijusius su aptariamomis problemomis. Šiame ir kituose tarptautiniuose forumuose praktiškai ne-

\footnotetext{
${ }^{17}$ AL Arabiya with AFP, „Saudi Aramco says cyber-attack targeted kingdom's economy“, Al Arabiya News, http://english.alarabiya.net/articles/2012/12/09/254162.html, 09122012.

${ }^{18}$ Perlroth N., „In Cyberattack on Saudi Firm, U.S. Sees Iran Firing Back „, New York TImes, http://www. nytimes.com/2012/10/24/business/global/cyberattack-on-saudi-oil-firm-disquiets-us.html, 23102012. ${ }^{19}$ Ten pat.

${ }^{20}$ Dunn J., „South Korean cyberattacks used hijacked patch management accounts“, http://www.pcworld. com/article/2031860/south-korean-cyberattacks-used-hijacked-patch-management-accounts.html\#tk. nl_today, PC World, 23032013.

${ }^{21}$ Transcript, Internet Governance Forum, http://www.intgovforum.org/cms/component/content/ article/102-transcripts2010/658-sop, 10092010.
} 
figūravo klausimas, kaip reikètų vertinti trečiąji kibernetinių grèsmių šaltinị, t. y. tam tikrų valstybių veiklą. Tų pačių valstybių, kurios yra aljansų narès ir kartu su kitomis dalyvauja konferencijose ir forumuose, prižiūrinčiuose kibernetinį saugumą, interneto laisvès ir gynybos politiką.

Tam tikros pastangos dèl valstybių dalyvavimo kibernetinèse atakose problemos sprendimo vis tik buvo dedamos. Šanchajaus bendradarbiavimo organizacija (Rusija, Kinija, Tadžikistanas, Uzbekistanas) iš tikrųjų $2011 \mathrm{~m}$. rugsèjo mèn. pateikè Jungtinių Tautų Generalinei Asamblëjai laišką, siūlydama Tarptautinị elgsenos kodeksą dẻl informacijos saugumo ${ }^{22}$. Tarp kitų pasiūlymų buvo ir pasiūlymas valstybèms susilaikyti ir nenaudoti šių technologijų prieš viena kitos ypatingos svarbos infrastruktūras. Tačiau Vakarų šalys jị greit atmetè ${ }^{23}$ kaip per daug šališką ir palankų autoritarinèms valstybėms, siekiančioms kontroliuoti informaciją kibernetinejje erdveje ir nepatogų socialinị-politinị aktyvumą. Šiuo atžvilgiu Vakarų valstybès pasirodè dviveidès, kadangi pačios senbuvès turi autoritarizmo požymių, to ịrodymas gali būti valstybès vidaus ir užsienio elektroninio šnipinėjimo atskleidimas 2013 m., kuris, manoma, apèmé netgi draugiškų valstybių elektroninius ryšius ${ }^{24}$.

ESBO bandè spręsti šią problemą. $2011 \mathrm{~m}$., Lietuvai pirmininkaujant ESBO, Vienoje ịvyko konferencija, kurioje buvo svarstoma ar ESBO patirtis ginkluotès kontrolès klausimais galètų būti taikoma kibernetinei erdvei. 2011 $\mathrm{m}$. vasarą ir rudeni šio straipsnio autorius dalyvavo diskusijose apie galimas kibernetinès erdvès Pasitikejimo ir saugumo ịtvirtinimo priemones (angl. Confidence- and Security-Building Measures, CSBM). Pagal ESBO sprendimą PC1039, neformali darbo grupé turejjo parengti CSBM projektą, kuris vèliau tais metais būtų pateiktas ministrų susitikimuose Vilniuje. Nors buvo aptarta daug pasiūlymų, nebuvo pateikta tokio, kuris kaip nors apribotų ar suvaržytų piktavališką valstybès veiklą kibernetinejje erdvejje ${ }^{25}$. Deja, bendro susitarimo nepavyko pasiekti ir ESBO ministrų susitikime jokių pasiūlymų dẻl CSBM nebuvo pateikta.

2012 m. pabaigoje, Dubajuje, JT Tarptautinè telekomunikacijų sąjunga (angl. International Telecommunication Union, ITU) organizavo Pasaulinę tarptautinių komunikacijų konferenciją (angl., World Conference on Inter-

\footnotetext{
${ }^{22}$ Maurer T., „Cyber norm emergence at the United Nations - An Analysis of the Activities at the UN Regarding Cyber-security“, Belfer Center for Science and International Affairs, http://www.un.org/en/ecosoc/ cybersecurity/maurer-cyber-norm-dp-2011-11.pdf, 09 2011, p.6668.

${ }^{23}$ Farnsworth T. , „China and Russia Submit Cyber Proposal“, Arms Control Association, http://www.armscontrol.org/act/2011_11/China_and_Russia_Submit_Cyber_Proposal 112011.

${ }^{24} \mathrm{BBC}$, „Brazil and Mexico probe claims US spied on presidents“, http://www.bbc.co.uk/news/world-latinamerica-23938909, 02092013.

${ }^{25}$ Aš žinau, nes buvau vienas iš tų, kurie bandè pateikti tokị pasiūlymą (aut. pastaba).
} 
national Telecommunications, WCIT). Ši konferencija buvo labai įdomi dèl daugelio priežasčių. ITU bandè skatinti atnaujinti būdą, kaip pasaulinès komunikacijos turètų būti reguliuojamos. Buvo pasiūlymų atnaujinti nuostatus ittraukiant tai, ko nebuvo paskutinị kartą tvirtinant reglamentą 1989 m., t. y. nuostatas apie internetą. Nors WCIT susitikimuose nepavyko pasiekti susitarimo dèl atnaujinto telekomunikacijų reglamento interneto atžvilgiu, jų metu buvo atskleista kita problema augantis nesutarimas tarp Rytų ir Vakarų interneto valdymo klausimais. Tapo akivaizdu, kad didejja susirūpinimas tarp Rytu valstybių (ypač Rusijos ir Kinijos) dèl Vakarų valstybių (ypač JAV) dominavimo, sprendžiant, kaip kontroliuoti internetą. Demokratinès šalys buvo linkusios palaikyti daugiašalị interneto valdymo būdą (su minimaliu vyriausybès dalyvavimu), o autoritarinès vyriausybės siekè didesnès vyriausybès kontrolès reguliuojant interneto turinị ir naudojimą. Interneto „laisvès“ šalininkams džiūgaujant dèl „JT nesèkmès „perimti internetą a"26, pavojingas skilimas tarp Rytų ir Vakarų dèl kibernetinès erdvès valdymo išliko ${ }^{27}$. Aptariant ši klausimą būtų verta paminèti dokumentą „Talino vadovas dèl tarptautinès teisès, taikytinos kibernetiniams karams" (toliau Talino vadovas). Jis buvo parengtas taip vadinamos nepriklausomos tarptautinès ekspertų grupès NATO Bendros kibernetinès gynybos kompetencijų centro Estijoje prašymu ${ }^{28}$. Šis Talino vadovas pateikia kibernetinès erdvès analizę ir gaires, kaip turi būti taikomos nustatytos tarptautinès normos naujoje kibernetinès erdvès srityje. Pateikti požiūriai ir duomenys nèra ịpareigojantys, bet tarptautinių ekspertų sąrašas rodo, koks svarbus ateityje bus šis Talino vadovas kaip elgsenos kibernetinejje erdvejje orientyras. Būtina pažymèti, kad ekspertai, prisidèję prie minèto Talino vadovo kūrimo, yra išimtinai iš Vakarų šalių, atstovų iš šalių (ypač iš Rytų), apimančių didžiąją dalị interneto vartotojų, nebuvo ịtraukta. Tai, kad šiame sąraše Rytų šalys praktiškai neatstovaujamos, nepadès bendrai priimti šio Talino vadovo kaip orientyrą, skirto politikos strategams, siekiantiems bendradarbiavimo sprendžiant kibernetinio saugumo klausimus. Tikimasi, kad rengiant atnaujintą Talino vadovo versiją, bus pakviesti dalyvauti plačiau atstovaujantys pasaulị ekspertai.

\footnotetext{
${ }^{26}$ Klimburg A., „The Internet Yalta“, Center for a New American Security, http://www.cnas.org/theinternetyalta, 0202 2013, p. 2.

${ }^{27}$ Gewirtz D., „Take action before the UN, Russia, and China hijack the Internet“, ZDNET, http:// www.zdnet.com/take-action-before-the-un-russia-and-china-hijack-the-internet7000008003/?s_ cid=e539\#postComment, 28112012.

${ }^{28}$ NATO Cooperative Cyber Defence Centre of Excellence, http://www.ccdcoe.org/249.html , 2013.
} 


\section{Kaip valstybės reagavo į savo kaimynų veiksmus kibernetinèje erdvèje?}

Kaip jau buvo minèta, tarptautinė bendruomenè nepadarè pakankamos pažangos kolektyviai reaguodama i̇ piktavališką kibernetinę valstybių veiklą kibernetinejje erdveje. Kibernetinè erdvè ir toliau lieka nevaldoma teritorija, panašia ị Laukinius Vakarus, kur nẻra šerifų ar raitụjų tvarkos sergètojų. Tačiau valstybès jau suvoke ši naują pavojų ir reagavo sukurdamos padalinius, kurių konkreti užduotis - kibernetinė gynyba. Tai nèra nereikšminga tendencija. $2007 \mathrm{~m}$. viena tyrimo studija nustatè, kad tokie padaliniai yra daugiau nei 120 šalių $^{29}$.

Pateikiame trumpą sąrašą šalių, kurių vyriausybès, kaip žinoma, turi kibernetinès gynybos ar puolimo padalinius: Australija, Belgija, Brazilija, Kanada, Kinija, Suomija, Vokietija, Indija, Iranas, Izraelis, Japonija, Malaizija, Pietų Koreja, Šiaurès Koreja, Jungtinè Karalystė, Rusija. Bene labiausiai viešai žinoma yra Jungtinių Valstijų reakcija ị piktavališką kibernetinę valstybių veiklą ${ }^{30}$. Tokia veikla kibernetineje erdveje yra rimta JAV problema, nes ji vis tampa kibernetinio šnipinejjimo ir kibernetinių atakų auka. Suprantama, kad valstybès pastebëjo, jog JAV traktuoja kibernetinę erdvę kaip „operatyvinę sritị ‘31, aktyviai kuria savo kibernetines pajègas, yra susijusi su Stuxnet tipo kibernetinių ginklų kūrimu, naudojimu ir yra ịtariama vidaus ir užsienio elektroninių ryšių sekimu.

Kinijos kariuomenè yra susijusi su kibernetinio karo padaliniu PLA 61398 , apie kurị buvo neseniai sužinota iš viešo pranešimo ${ }^{32}$. Informacijos apie Rusijos vyriausybès kibernetinius padalinius ${ }^{33}$ buvo paviešinta mažiau, tačiau atrodo, kad ji ne mažiau aktyvi negu kitos didžiosios kibernetinès valstybès. Atrodo, kad Australijos ryšių direktoratas nori, kad visiems būtų žinoma apie jo planus. Jo interneto svetainès moto yra „Atskleisk jų paslaptis, savą-

\footnotetext{
${ }^{29}$ „In the Crossfire“, McAfee, http://www.mcafee.com/us/resources/reports/rp-in-crossfire-critical-infrastructure-cyber-war.pdf, 2009.

${ }^{30}$ Sanger D., „Budget Documents Detail Extent of U.S. Cyberoperations“, New York Times, http://www. nytimes.com/2013/09/01/world/americas/documents-detail-cyberoperations-by-us.html, 31082013.

${ }^{31}$ U.S. Depatarment of Defense, Department of Defense Strategy for Operating in Cyberspace, http://www. defense.gov/news/d20110714cyber.pdf 1707 2011, p. 5.

${ }^{32}$ Mandiant, APT1 Exposing One of China's Cyber Espionage Units, http://intelreport.mandiant.com/, 2013.

${ }^{33}$ Sridharan V., „Russia Setting up Cyber Warfare Unit Under Military“, International Business Times, http://www.ibtimes.co.uk/articles/500220/20130820/russia-cyber-war-hack-moscow-military-snowden. htm, 20082013.
} 
sias saugok ${ }^{\text {“34 }}$. Valstybès taip pat aktyviai naudojasi konjunktūra, siekdamos gauti kuo daugiau informacijos apie kibernetinių atakų rengimą ir ginkluotę joms vykdyti ${ }^{35}$. Vertingiausia yra informacija apie neskelbiamus programinès ịrangos pažeidžiamumus, žinomus kaip „nulinè diena“. Informacija apie šiuos pažeidžiamumus, kurią galima labai sẻkmingai panaudoti, galètų sudaryti sąlygas ne vienam programišiui praturtèti ir, galbūt, padètų jam gauti darbą su vyriausybe susijusiose institucijose. Kokia motyvacija slypi už šios veiklos, kuri prilygsta Šaltajam karui ir yra panaši ị kibernetinio ginklavimosi varžybas tarp valstybių?

Galbūt, valstybès jau suprato, ką reiškia Stuxnet. Stuxnet parodè, kad kenkejjiška programinè ịranga gali būti sukurta kaip kibernetinis ginklas, nukreiptas prieš ypatingos svarbos valstybès infrastruktūrą. Padaryta žala gali būti reali ir, priešingai nei raketų ataka, ji nesukelia adekvataus atsako ir palieka labai mažą galimybę susekti ir nustatyti kaltininko buvimo vietą. Kibernetini ginklą naudoti yra naudinga. Taip, jis yra brangus, tačiau pigesnis už reaktyvinį naikintuvą ar bombonešį. Pavyzdžiui, išlaidos kuriant, bandant ir paleidžiant Stuxnet, galejo kainuoti apie 10 milijonų JAV dolerių ${ }^{36}$. Tai tikrai maža kaina už gerai ịtvirtintų požeminių irenginių darbo nutraukimą, užpuolikui nepatiriant nuostolių ir liekant neapkaltintam. Palyginti mažos išlaidos ir atsakomybè yra du pagrindiniai privalumai, kuriuos turi valstybės, siekiančios efektyvaus, saugaus būdo be realios atsakomybès, noredamos pasiekti nepavykusios užsienio politikos tikslų. Gali būti, kad valstybès jaučiasi verčiamos vystyti kibernetinius gynybos (puolimo) pajègumus, siekdamos apsiginti nuo tokių atakų ir jas atgrasyti. Nors apie Stuxnet daug rašyta nuo tada, kai jis pirmą kartą buvo aptiktas 2010 metais, tačiau tarptautinèje bendruomenejje ir dabar tebetvyro keista tyla. Valstybès siekia gauti informacijos apie „nulinès dienos" (angl. zero day) pažeidžiamumus, ketindamos apsiginti arba norédamos panaudoti ją savo pačių puolamosioms operacijoms. Tačiau šis susirūpinimas, panašiai kaip jūros vandens gérimas, kai esi ištroškęs, gali duoti priešingą rezultatą, skaidrumo ir pasitikejimo prasme.

Kai kurios didžiosios kibernetinès valstybès, tokios kaip JAV, mėgino demonstruoti tam tikrą lyderystę, skatindamos sukurti bendrąją kibernetinès erdvės politiką. Pavyzdžiui, 2011 metų gegužès mèn. JAV vyriausybė paskelbė

\footnotetext{
${ }^{34}$ Australian Government, Department of Defence, http://www.dsd.gov.au/, 2013.

${ }^{35}$ Perlroth N., Sanger D., „Nations Buying as Hackers Sell Flaws in Computer Code“, New York Times, http://www.nytimes.com/2013/07/14/world/europe/nations-buying-as-hackers-sell-computer-flaws.html, 13072013.

${ }^{36}$ Langner R., ,The short path from cyber missiles to dirty digital bombs", Langner Communications $\mathrm{GmbH}$, http://www.langner.com/en/2010/12/26/the-short-path-from-cyber-missiles-to-dirty-digitalbombs/, 26102010 .
} 
savo „Tarptautinę kibernetinès erdvės strategiją “" ${ }^{37}$. Ji skelbė savo tikslą tarptautinei bendruomenei: „skatinti atvirą, suderinamą, saugią, patikimą informaciją ir ryšių infrastruktūrą, kuri remia tarptautinę prekybinę ir komercinę veiklą, stiprina tarptautini saugumą ir skatina laisvos valios išraišką ir inovacijas. Siekdami šio tikslo, mes sukursime ir išlaikysime tokią aplinką, kurioje atsakingos elgsenos normos lemia valstybès veiksmus, palaiko partnerystę ir remia teisinès valstybès principus kibernetinèje erdvèje. " ${ }^{\text {"38 }}$ Iš tiesų, i̇spūdingas pareiškimas, kurị padare viena iš pagrindinių kibernetinių valstybių pasaulyje apie bendrąją politiką kibernetinèje erdveje. Tačiau jis buvo pateiktas praejjus dvejiems metams po Stuxnet paleidimo (veiksmo, kurị daugelis didžia dalimi priskiria pačioms Jungtinèms Amerikos Valstijoms) ${ }^{39}$. Minètos strategijos išleidimas tuo metu, kai Stuxnet atsirasdavo daugelyje pasaulio kompiuterių, vertè matyti JAV kibernetinę politiką kaip piktavališką ir kaip nepiktybinę tuo pačiu metu. Negalima kaltinti kitų valstybių, jei jos yra sutrikusios. Jos, matyt, norètų žinoti, ar JAV žiūri ị kibernetinę erdvę kaip ị bendradarbiavimo aplinką ar kaip ị erdvę konfliktams ${ }^{40}$.

Matyti, kad kai kurios valstybės neprièmė JAV pasiūlymo dèl taikaus kibernetinès erdvės panaudojimo, kur būtų vadovaujamasi teisinès valstybės principais. Vietoj to jos ėmèsi atsakomųjų priemonių. Pavyzdžiui, po 2012 metų balandžio mèn. įvykdytos Stuxnet kibernetinès atakos prieš Irano branduolinį objektą ir po kibernetinès atakos prieš kitą jos ypatingos svarbos infrastruktūros dali (naftos pramonę) $)^{41}, 2012 \mathrm{~m}$. gruodžio mèn. buvo surengta kibernetinè ataka prieš Saudo Arabijos naftos pramonę $e^{42} .2012$ metų pabaigoje ir 2013 metų pradžioje rimtos kibernetinès atakos buvo nukreiptos prieš JAV finansų sistemą ${ }^{43}$. Dèl šių atakų Jungtinès Valstijos tuoj pat apkaltino Iraną ${ }^{44}$. Turint galvoje šias augančio masto ir ilgai trunkančias atakas prieš energetikos ir finansų sektorius, kyla klausimas, ar situacija netampa nekontroliuojama.

\footnotetext{
${ }^{37}$ The White House, International Strategy for Cyberspace, http://www.whitehouse.gov/sites/default/files/ rss_viewer/international_strategy_for_cyberspace.pdf, 052011.

${ }^{38}$ Ten pat, p. 8 .

${ }^{39}$ Sanger D., „Obama Order Sped Up Wave of Cyberattacks Against Iran“, New York Times, http://www. nytimes.com/2012/06/01/world/middleeast/obama-ordered-wave-of-cyberattacks-against-iran.html?_r=0, 01062012.

${ }^{40}$ Healey J, A Fierce Domain: Conflict in Cyberspace, 1986 to 2012, Cyber Conflict Studies Association, 2013, p. 77.

${ }^{41}$ Roberts P., „Iran Acknowledges Hack Of Oil Ministry“, Threat Post, http://threatpost.com/iran-acknowledges-hack-oil-ministry-042312/76470, 23042012.

${ }^{42} \mathrm{Al}$ Arabiya and AFP, „Saudi Aramco says cyber attack targeted kingdom's economy“, Al Arabiya News, http://english.alarabiya.net/articles/2012/12/09/254162.html , 09122012.

${ }^{43}$ Rothman P., „Cyber terror rages in the banking sector“, http://www.securityinfowatch.com/ blog/10796084/cyber-terror-rages-in-the-banking-sector , 28092012.

${ }^{44}$ Perlroth N., „In Cyberattack on Saudi Firm, U.S. Sees Iran Firing Back“, New York Times, http://www. nytimes.com/2012/10/24/business/global/cyberattack-on-saudi-oil-firm-disquiets-us.html, 23102012.
} 


\section{Kur tai veda ir kodèl reikia kažką daryti, siekiant apsaugoti kibernetinę erdvę?}

Kaip visa tai veikia taiką ir stabilumą? Kibernetinių ginklų, kaip pigaus, efektyvaus būdo be realios atsakomybès, siekiant kitaip nepasiekiamų užsienio politikos tikslų, patrauklumas, neliko valstybių nepastebètas. Šie ginklai gali būti panaudoti, norint sužlugdyti arba sunaikinti slaptą informacinę technologiją ir ịvairius telekomunikacijų komponentus. Tai, apie ką kalbame, ir yra svarbūs strateginiai elementai, kurie sudaro svarbiausių nacionalinių infrastruktūrų, atsakingų už elektros energijos gamybą, telekomunikacijas, finansų sistemas, transportą ir kitas struktūras, kurių funkcionavimas užtikrina gyvybiškai svarbias paslaugas šiuolaikinių pramoninių valstybių ekonomikai ir socialinei gerovei, pagrindą. Tas faktas, kad kaltès priskyrimas, t. y. atsakingu už atakas nustatymas, yra labai sudètingas, suteikia pranašumo užpuolikui, ieškančiam lengvų būdų žalai padaryti. Kita vertus, tiems, kurie rūpinasi gynyba, tai sukelia ịtarimą ir verčia jaustis nesaugiai kaimynų ketinimų atžvilgiu. Kodèl mano kaimynas mane šnipinejja? Kodèl mano kaimynai kuria kibernetines pajègas? Ką jie planuoja daryti (ar jau daro) su jomis? Gal ir man reikia tokias pajègas sukurti? Sunku rasti ịtikinamų atsakymų ị šiuos klausimus tokioje mažo skaidrumo ir menko pasitikejimo aplinkoje. Sunku nesutikti su tais, kurie kalba apie kibernetinio ginklavimosi varžybų pradžią ${ }^{45}$.

Reikia atsižvelgti ir ị tai, kokị spaudimą gali patirti vadovai, verčiami kaip nors veikti, kai atakuojama svarbi jų valstybės infrastruktūra. Visiškai imanoma, kad pasirinkus atsakomąsias priemones, jos gali būti nukreiptos prieš nekaltą šalį, o ne prieš tikrąją kaltininkę. Pavyzdžiui, yra kai kurių požymių, kad kibernetinė ataka, nukreipta prieš Pietų Korẻją 2013 metų pavasarị, galèjo būti sukurta arba Šiaurès Korejjoje, arba Kinijoje ${ }^{46}$. Kaip šalis gali būti tikra, kad ji teisingai nustatè atakos kaltininkę? Šis tikrumo trūkumas, susijęs su kaltininko nustatymu, yra dar vienas santykių nestabilumo požymis.

Kibernetinès erdvès naudojimas yra klausimas, dèl kurio kyla rimtų nesutarimų tarp didžiụjų valstybių. Tai, kaip šios valstybès reaguoja, taip pat didina jų tarpusavio santykių ir santykių su kitomis valstybėmis, patekusiomis $\mathfrak{t}$ „kryžminę ugnị “, nestabilumą. JAV ir Kinijos tarpusavio kaltinimai dèl kibernetinio šnipinèjimo ir viena kitos ypatingos svarbos infrastruktūrų kiber-

\footnotetext{
${ }^{45}$ Guy-Philippe Goldstein, „How cyberattacks threaten real-wold peace“, Ted Conferences, http://www.ted. com/talks/guy_philippe_goldstein_how_cyberattacks_threaten_real_world_peace.html, 102011.

${ }^{46}$ Donohue B., „South Korea Blames North Korea for March Cyberattack“, Threat Post, http://threatpost. com/south-korea-blames-north-korea-march-cyberattack-041013, 13042013.
} 
netinè žvalgyba yra geri to pavyzdžiai ${ }^{47}$. Svarstydamas galimus JAV motyvus, slypinčius Stuxnet sukūrime, vienas iš komentatorių pateikè nerimą keliančią išvadą. Jis teigia, kad ši kibernetinè supervalstybè, reaguodama $\mathfrak{i}$ atakas prieš savo kibernetinès erdvės objektus, panaudojo Stuxnet norėdama pranešti savo potencialiems priešininkams: „Gerai pagalvokite, prieš atakuodami mus. Tai pavyzdys to, ką galime padaryti. Mes ir vèl tai padarysime. ${ }^{“ 48}$ Galbūt galima suprasti norą atgrasinti potencialų agresorių, giriantis savo kibernetine ginkluote, tačiau kibernetinès erdvès naudotojui, gyvenančiam ne JAV, maža paguoda. Neteisinga galvoti, kad kibernetinis ginklas turi būti naudojamas, norint atgrasinti ir daryti įtaką kitiems, siekiant, kad jie elgtųsi kitaip. Daugeliu atvejų, tai sugebejjimas, kuri gali vienodai turèti tiek galingosios, tiek ir ne tokios galingos valstybès. Nepaisant didelių branduolinio klubo narystès reikalavimų, šiandien bet kuri valstybe gali sukurti arba įsigyti rinkoje savo skaitmeninị kodą kibernetiniam ginklui ir gali tapti kibernetine valstybe.

Dar vienas susirūpinimą keliantis dalykas yra tas, kad valstybių ypatingos svarbos infrastruktūros yra stipriai susijusios tarpusavyje. Kibernetinè erdve ir yra ta aplinka, kurioje vyksta šiuolaikine prekyba ir tarptautiniai ryšiai. Piktybiškai nusiteikusi valstybė ar aktyvi patriotiška „kibernetinė kariuomené, atsakydama ị kibernetinę ataką ir nukreipdama savo kibernetinę ginkluotę prieš šalị tariamą kaltininkę, gali sukelti nenuspèjamas pasekmes. Taip yra dèl to, kad kibernetinè erdvé visame pasaulyje yra labai susijusi su kitais tinklais ir sistemomis. Atakos (ir bet kokios kontratakos, kurių bandytų imtis taikinys), greičiausiai, pereitų per nenuspejjamą skaičių tinklų ir sistemų, esančių kitose šalyse. Tikètina, kad dèl ypatingos svarbos infrastruktūros tarpvalstybinio pobūdžio (pavyzdžiui, dèl bendrų elektros tinklų arba dujų vamzdynų) tokių konfliktų padariniai palies ir kitas nacionalines infrastruktūras ir institucijas ${ }^{49}$. Atsakomosios operacijos ị kurios nors valstybès kibernetinę ataką, manant, jog toji yra už ją atsakinga, gali turèti neprognozuojamų pasekmių, nepaisant to, kad tai galètų būti pateisinama.

Netgi kibernetinio šnipinėjimo atveji galima interpretuoti kaip karinị veiksmą (tiesą sakant, taip manė JAV, kai ji nustatė Rusijos vykdomą kiberne-

\footnotetext{
${ }^{47}$ Healey J., A Fierce Domain: Conflict in Cyberspace, 19862012, Cyber Conflicts Studies Association, 2013, p. 171-173.

${ }^{48}$ Morton C., „Stuxnet, Flame, and Duqu - the Olympic Games“ in Healey J., ed., A Fierce Domain: Conflict in Cyberspace, 1986-2012, Cyber Conflicts Studies Association, 2013 p. 231.

${ }^{49}$ National Research Council of the National Academies, Technology, Policy, Law, and Ethics Regarding U.S. Acquisition and Use of Cyberattack Capabilities, http://www.nap.edu/openbook.php?record_ id=12651\&page=R1, The National Academies Press, 2009, p.4649.
} 
tinio šnipinejimo atveji $)^{50}$. Kai kas gali paskubèti priimti kibernetinị šnipinèjimą kaip dalị priimtos „realiojo“ pasaulio tvarkos. Iš tikrųų, viskas yra kitaip, kai šnipinèjimas vykdomas elektroniniu būdu kibernetinèje erdveje. Skirtingai nuo tradicinio šnipinèjimo, kai žmogus vagia informaciją, kibernetinio šnipinèjimo veikla yra specifinè, nes elektroniniam šnipui ịsiskverbus ị sistemą, reikia labai mažai pastangų, norint pereiti nuo šnipinejjimo (dokumentų parsisiuntimo) iki sabotažo veiksmų. Šnipas gali palikti loginę bombą pagrindinėje sistemoje, kuri vèliau pagal komandą galètų suveikti. Tai vadinama mūšio lauko parengimu. İsiskverbus ị sistemą ir joje įsitvirtinus, beveik nebelieka skirtumo, kuris veiksmas vykdomas šnipinejjimo ar sabotažo. Užtenka nuspausti ENTER klavišą. Tokia kovos lauko parengimo veikla, jei ją aptinka auka, gali būti labai provokuojanti ir tam tikros įtampos metu gali lengvai peraugti ị rimtą konfliktą.

Dar viena ittampos tarp valstybių priežastis yra kibernetinès atakos kaip ịrankis, siekiant daryti ịtaką kaimynų vidaus politikai ${ }^{51}$. Pavyzdžiui, galimas dalykas, jog būtent tai buvo kibernetinès atakos prieš Estiją 2007 metais pagrindas. Suaktyvejjo patriotinès riaušininkų grupuotès, remiančios savo vyriausybės (šiuo atveju - Rusijos) politiką arba propaguojančios savo pačių programąa ${ }^{52}$. Kaip valstybės toliau spręs šių savanoriškų „kibernetinių karinių grupuočių" veiksmus santykių su kitomis valstybėmis atžvilgiu? Kaip jos reaguos ị kitų vyriausybiu nusiskundimus dèl atakų, kurias surengè šios kariuomenès, esančios jų teritorijoje?

Pranašumai, kuriuos potencialiam užpuolikui suteikia kibernetiniai ginklai, t. y. jų ekonomiškumas ir „nepakaltinamumas“, labai vilioja. Valstybès pripažista, kad jos tampa vis labiau priklausomos nuo kibernetinès erdvès tam, kad galètų augti jų ekonomika ir visuomenès gerovè. Jei nėra jokios kibernetinès policijos, kurią prireikus galima būtų pasitelkti, valstybès ir toliau kuria savo kibernetinius pajegumus. Šioje netikrumo ir ịtarumo aplinkoje bet koks kibernetinis konfliktas gali greitai peraugti $\mathfrak{x}$ didesnius tarpvalstybinius konfliktus. Taip pat tiketina, kad kartu su bet kokiu tradiciniu tarpvalstybiniu konfliktu bus ir kibernetinès atakos komponentų, kurie apsunkins to konflikto sprendimą. Logiška, kad tarptautinès organizacijos yra vieta, kur galima būtų ieškoti „teisejjų“ šiose naujose ir potencialiai žlugdančiose varžybose.

\footnotetext{
${ }^{50}$ Elkus A., „Moonlight Maze“ in Healey J., ed., A Fierce Domain: Conflict in Cyberspace, 19862012, Cyber Conflicts Studies Association, 2013, p. 152160.

${ }^{51}$ Healey J., A Fierce Domain: Conflict in Cyberspace, 19862012, Cyber Conflicts Studies Association, 2013, p. 191.

${ }^{52}$ McAfee Labs, McAfee Threats Report: First Quarter 2013, McAfee, http://www.mcafee.com/us/resources/ reports/rp-quarterly-threat-q1-2013.pdf, 2013, p. 33.
} 


\section{Ką gali padaryti tarptautinè bendruomenè, norèdama sumažinti konflikto, kylančio dèl piktavališkos valstybių veiklos kibernetinėje erdvèje, eskalavimo pavojų?}

Užduotis siūlyti sprendimus dẻl piktavališkos valstybių veiklos kibernetinejje erdvejje negali būti priskirta aukštujjų technologijų specialistams, dirbantiems Informacinių technologijų ministerijoje ar ịsigijimų departamentuose, teisètvarkos institucijose, slaptosiose žvalgybos tarnybose ar sukarintuose kibernetiniuose padaliniuose. Šias sudètingas problemas, ị kurias įeina reagavimas ir susidorojimas su šios tarptautinę dimensiją turinčios veiklos padariniais, gali išspręsti tik politikai ir saugumo politikos formuotojai. Norint pasiekti konkrečiu rezultatų, ši darbą reikia atlikti susitelkusios tarptautinès bendruomenès, kuri įsipareigojusi sukurti tarptautiniu mastu privalomus sprendimus, kontekste. Šis tikslas būtų: sukurti tarptautinị susitarimą dẻl valstybių elgsenos normų ir pasitikejimo didinimo, atsakomybès ir skaidrumo tarp valstybių kibernetinėje erdveje.

Pasiūlymai, kaip spręsti netinkamos valstybių elgsenos kibernetinëje erdvejje klausimą:

1. Isipareigojimas susilaikyti nuo piktavališkos kibernetinès veiklos, nukreiptos prieš ypatingos svarbos civilinę infrastruktūra (finansu, energijos tiekimo, transporto ir telekomunikaciju).

Argumentai. Noras apsaugoti valstybinę ekonomiką ir civilius gyventojus nuo finansinių nuostolių ir fizinès žalos turi būti bendras visoms valstybèms. Dèl tam tikros valstybès veiklos kibernetinèje erdveje valstybių tarpusavio santykiuose gali atsirasti klaidingas supratimas ir nestabilumas. Pavyzdžiui, loginių bombų ar „užpakalinių durų“ panaudojimas valstybès ypatingos svarbos informacijos infrastruktūroje gali būti neteisingai suprastas kaip pasirengimas mūšiui ir gali sparčiai padidinti ịtampą. Kibernetinè veikla, nukreipta prieš kitos valstybès ypatingos svarbos infrastruktūrą, dèl finansų sistemų, elektros tinklų, vamzdynų ir kitos šiuolaikinès ypatingos svarbos infrastruktūros integracijos taip pat gali turèti didelị tarpvalstybinị ar net regioninị poveikị.

Kažkas panašaus jau buvo minèta pasiūlymuose, kuriuos pateikè tiek Rytų, tiek Vakarų atstovai. Vieną iš jų pateikè valstybė, kuri yra glaudžiai susijusi su Stuxnet. Savo paskutinëje knygoje „Kibernetinis karas“ Richardas Clarke'as, buvęs keleto JAV prezidentų patarejjas saugumo klausimais, pasitelkè savo didelę patirtị branduolinès ginkluotès kontrolès klausimais, pritaikyda- 
mas ją kibernetinei erdvei. Perskaitykite jo pasiūlymą dèl Kibernetinio karo apribojimo sutarties ${ }^{53}$. Pasiūlymas, draudžiantis kibernetinių ginklų naudojimą prieš ypatingos svarbos infrastruktūras, yra ịtrauktas ir ị Šanchajaus bendradarbiavimo organizacijos pasiūlymus dèl Tarptautinès elgsenos kodekso, 2011 metais buvo nusiųstas i jT $\mathrm{T}^{54}$.

Pažado susilaikyti neužtenka. Būtina prisiimti atsakomybę dèl savo ịsipareigojimų vykdymo. Iš to atsiranda antrasis pasiūlymas.

2. Isipareigojimas dèl valstybinès kibernetinès erdvès teisinès atsakomybès. Valstybès sutinka prisiimti atsakomybę dèl piktavališkos kibernetinès veiklos, vykstančios ju jurisdikcijos kibernetinèje erdvèje arba einančios per ją.

Argumentai. Valstybès privalo susitarti dèl minimalių ịsipareigojimų tam, kad apsaugotų savo nacionalinę kibernetinę erdvę. Reikia ypač pabrèžti valstybiu ịsipareigojimą reaguoti $\mathfrak{i}$ incidentus, kylančius iš arba einančius per tų valstybių jurisdikcijos kibernetinę erdvę. Pavyzdžiui, valstybės turètų užtikrinti, kad nacionaliniai interneto paslaugų teikejjai ir teisėsaugos institucijos imtųsi reikiamų priemonių prieš asmenis, grupes taip pat ir informacinę ir ryšių įrangą, kurie, kaip yra nustatyta, dalyvauja kibernetinejje atakoje. Tuo taip pat norima pasakyti, kad valstybès sutinka sukurti pajègumus, kurie yra reikalingi spręsti kibernetinio saugumo klausimus. Tai reiškia atitinkamų i̊statymų ir struktūrų (nacionalinių kompiuterių incidentų reagavimo tarnybų, teisètvarkos subjektų ir t. t.), kurių reikia, norint vykdyti ši įsipareigojimą, sukūrimą.

Tai irgi nèra nauja idèja. JAV mokslininkai jau kurị laiką diskutuoja apie poreikị valstybėms prisiimti ịsipareigojimus už tai, kas vyksta jų kibernetinės jurisdikcijos ribose. Tokios politikos mąstymo pavyzdys gali būti Chriso C. Demchako ir Peterio Dombrowskio straipsnis, kuriame kalbama apie kibernetines sienas ir jurisdikcijos ribas. Jie teigia, kad kibernetinè erdvė nebera bendra teritorija, kur bet kas gali klajoti ir daryti, ką panorėjęs. Yra tiek daug visko sukurta ir taip rizikuojama valstybès saugumu, kad kibernetinių sienų sukūrimas ir kontrolè yra svarbus žingsnis, užtikrinant ypatingos svarbos infrastruktūrų apsaugą nuo kibernetinių pavojų ${ }^{55}$.

\footnotetext{
${ }^{53}$ Clarke R., Cyber War: The Next Threat to National Security and What to do About it, Harper Collins, 2010, p. 268271.

${ }^{54}$ Ministry of Foreign Affairs of the People's Republic of China, „China, Russia and Other Countries Submit the Document of International Code of Conduct for Information Security to the United Nations", Ministry of Foreign Affairs of the Peoples Republic of China, http://www.fmprc.gov.cn/eng/wjdt/wshd/ t858978.htm, 13092011.

${ }^{55}$ Demchak C., Dombrowski P., „Rise of a Cybered Westphalian Age“, Strategic Studies Quaraterly 5 (1), http://www.au.af.mil/au/ssq/2011/spring/spring11.pdf, 2011, p. 5457.
} 
Su teisinemis atsakomybemis ir įsipareigojimais yra siejama kaltès priskyrimo problema. Reikia padaryti taip, kad vykdyti kibernetines atakas būtų sudètingiau, o tikimybè būti pagautam būtų didesnè. Kai valstybè nustatys savo kibernetines sienas ir jas kontroliuos, kibernetinems atakoms bus daug sunkiau išlikti nepastebètoms. Tačiau iki šiol buvusios nesèkmingos pastangos, mėginant nustatyti kaltininkus, turi būti perkeltos nuo mèginimo nustatyti, kas faktiškai atakuoja, $\mathfrak{i}$ tai, „kuri valstybè, jei tokia yra, atsakinga “56. Būtent valstybe turi būti atsakinga už tai, kad būtų užtikrinta kontrolè jos kibernetinių sienų ribose ir kad piktavališka kibernetinè veikla, atsiradusi arba einanti per jos kibernetinę jurisdikciją, būtų stebima ir kontroliuojama. Visa atsakomybè už reagavimą ir atakos tyrimą turi būti taikoma ne aukai, bet tiems, kurie yra arčiausiai ir kurie gali reaguoti i i incidentą.

3. Stebëjimas, kaip igyvendinami aukščiau išdesstyti suderinti ịsipareigojimai. Valstybès turètų paremti sudaryti iš savanorių ekspertų ir institucijų, kurie stebètų ir patartų dviejų aukščiau aptartų punktų vykdymo klausimais, koaliciją.

Argumentai. Turi būti prieinamos tam tikros priemonès, norint stebèti ir informuoti dalyvaujančias valstybes apie piktavališką kibernetinę veiklą, kuri vyksta jų kibernetinès jurisdikcijos ribose arba eina per ją. Reikia sukurti instituciją, kurią sudarytų ekspertai, galintys stebėti ir teikti objektyvų vertinimą apie ịsipareigojimų pažeidimus. Tokiu būdu būtų numatyta galimybė daryti švelnųji spaudimą valstybėms, kurios delsia arba nenori imtis veiksmų dèl nustatytos piktavališkos veiklos, vykstančios jų kibernetineje jurisdikcijoje.

Tai nèra naujiena bet kam, kas dirba tarptautinių santykių srityje. Tai nèra naivus idealizmas. Tais klausimais, kur suvokiama būtinybẻ ir kur yra tikrai svarbu, valstybès susivienijo ir pasirašè tarptautinius susitarimus ir konvencijas. Tai ypač pasakytina apie masinio naikinimo ginklų draudimą. Vienas modelis, kaip būtų galima spręsti klausimą, susijusị su valstybių kibernetinių ginklų gamyba ir panaudojimu, yra tarptautinè Cheminio ginklo konvencija. Galbūt, vis dar prisimenant jų panaudojimą Pirmajame pasauliniame kare ir pripažistant technologijų pažangą, kuri gali palengvinti cheminių ginklų panaudojimą ir padidinti jų galimybę padaryti žalą, ši konvencija issigaliojo 1997 metais. Ją pasiraše daugiau nei 190 valstybių, atstovaujančių $98 \%$ pasaulio gyventojų. Kartu su šiuo susitarimu buvo sukurta Cheminio ginklo draudimo organizacija (angl. Organisation for the Prohibition of Chemical Weapons, OPCW), kurios

\footnotetext{
${ }^{56}$ Healey J., ed., A Fierce Domain: Conflict in Cyberspace, 1986 to 2012, Cyber Studies Conflict Association, 2013, p. 265.
} 
tikslas yra stebèti ir kontroliuoti, kaip ši konvencija yra igyvendinama ${ }^{57}$. Cheminio ginklo konvencija gali pasitarnauti, svarstant trijų anksčiau minètų pasiūlymų igyvendinimą. Rašant šị straipsnị, OPCW aktyviai prisidèjo, sprendžiant Sirijos krizę. 2013 metais šios organizacijos nuopelnai buvo pripažinti tarptautiniu mastu, kai OPCW buvo skirta Nobelio taikos premija.

Azijos Ramiojo vandenyno tinklų ir informacijos saugumo incidentų tyrimų grupè (angl. Asia Pacific Computer Emergency Response Team, APCERT) yra regioninio bendradarbiavimo pavyzdys. APCERT sudaro nacionalinès tinklų ir informacijos saugumo incidentų reagavimo tarnybos ir interneto paslaugų tiekejjai Japonijoje, Kinijoje ir Pietų Korejoje. APCERT traktuoja „internetą ir jo būklę kaip vientisą bendrai naudojamą infrastruktūrą ${ }^{\text {"58 }}$. Šiai koalicijai pavyko išspręsti kibernetinius incidentus, kylančius dèl politinių konfliktų tarp jos narių ${ }^{59}$.

Tokio efektyvaus visuotinio reagavimo ị suvoktą bendrą grèsmę kibernetinejje erdveje pavyzdys yra CONFICKER darbo grupès veikla 20082009 metais. Vyriausybėms didžia dalimi nepavyko suvokti augančio pavojaus internetui, kurị sukèlè CONFICKER viruso kūrëjas, užkrèsdamas vis daugiau kompiuterių, kuriems bet kuriuo metu buvo galima duoti komandą veikti. Norẻdami apsaugoti internetą nuo šio naujo ir potencialiai sunaikinančio viruso, darbo èmėsi savanorių grupé, ị kurią ịejo gabūs privatūs asmenys, interneto paslaugų tiekejjai ir nevyriausybinès organizacijos. Ši pagrindinè asmenų grupé sugebejo pakankamai išvystyti bendradarbiavimą tarptautiniu mastu, kad galima būtų analizuoti, stebèti ir neutralizuoti interneto „bombą“, kokia buvo CONFICKER $^{60}$. Tai tik keletas pavyzdžių, ką gali nuveikti motyvuota tarptautinè bendruomenè.

\section{Išvados}

Kibernetinès erdvès, kuri yra daugiau negu visuomeninis internetas, jau nebegalima paprastai suvokti kaip globalios bendro naudojimo vietos, kurioje galima tvarkyti savo verslo reikalus, lankytis tinklalapiuose arba skaityti elektronini paštą. İ ją reikia žiūrèti kaip ị sritị, kuri yra ypač svarbi valstybès

\footnotetext{
${ }^{57}$ Organisation for the Prohibition of Chemical Weapons, http://www.opcw.org/chemical-weaponsconvention/.

${ }^{58}$ Ito Y., „Making the Internet Clean, Safe and ReliableAsia Pacific Regional Collaboration Activities", The Institute of Electrical and Electronics Engineers, http://ieeexplore.ieee.org/stamp/stamp. jsp?tp=\&arnumber $=59787962011$.

${ }_{59}^{59}$ Ten pat.

${ }^{60}$ Bowden M., Worm:The First Digital War, Atlantic Monthly Press, 2011, p. 221.
} 
ir jos piliečiu gerovei. Faktas, kuris taptų skausmingai akivaizdus tuo pačiu momentu, kai vienas iš svarbių procesų arba paslaugų yra nutraukiamas daugiau nei keletui valandų. Šioje erdvejje egzistuoja gyvybiškai svarbūs dalykai, kurie tapo pažeidžiami ir turi būti apsaugoti. Neseniai paskelbta informacija apie kibernetinių nusikaltèlių ir politinių programišių suėmimus, nors ir labai sveikintina ir gerai iliustruoja bendradarbiavimą ir augantį teisėsaugos veiksmingumą, rodo, jog saugi kibernetinè erdvė yra užtikrinama tik iš dalies. Kibernetinių nusikaltimų kaina nerodo tikrojo pavojaus masto. Pasaulio ekonomikos požiūriu ši kaina faktiškai galètų, kaip spëjama viename iš mokslinių darbų, siekti ne daugiau suapvalintos paklaidos dydžio nuo 14 trilijonų metinès ekonomikos ${ }^{61}$. Neproporcingai daug dèmesio skiriama informacijos ir informacinių sistemų (klaidingai vadinamomis ypatingos svarbos informacinèmis infrastruktūromis) apsaugai nuo kibernetinès atakų. Tikrasis pavojus, ¿̇ kurị reikia atsižvelgti, saugant kibernetinę erdvę, yra nekontroliuojama piktavališka valstybių veikla kibernetinejje erdvèje. Ypač ta veikla, kuria siekiama paralyžiuoti valdymo sistemas ir elektros tinklų, dujų vamzdynų, transporto sistemų ir kitų paslaugų, kurios yra svarbiausios šiuolaikinei civilizacijai, funkcionavimą. Kai kibernetinès erdvės valdymas yra patikètas fizikos dėsniams ir, nors prižiūrimas aukštos kvalifikacijos technologų, visos problemos negali būti išspręstos. Kibernetinè erdvè taip pat negali būti naudojama sprendžiant dabar pasaulyje vykstančius konfliktus. Buvusio JAV CŽV samdomojo darbuotojo E. Snowdeno paviešinta informacija apie vyriausybès ilgalaikį visuotinị šnipinëjimą ir ilgalaikes kenksmingas kibernetinès veiklos programas 2013 metų vasarą demonstruoja ne tik žmogaus teisių pažeidimus ir demokratinès valstybès tendenciją elgtis taip, kaip elgiasi autoritarinès valstybès, bet ir informuoja ir i̊spejja visuomenę apie tai, kokias nekontroliuojamas kibernetines galias turi vyriausybès savo rankose.

Nesenai vykusiame Sirijos konflikte buvo siūloma humaniškai pademonstruoti kibernetinius ginklus ${ }^{62}$. Šis faktas verčia prisiminti kai kuriuos 1945 metų svarstymus dèl pirmosios atominès bombos panaudojimo - i̇spejamojo jos demonstravimo. Labai abejotina, ar spaudžiant ENTER klavišą, galima išspręsti sudètingus konfliktus, tokius kokie dabar vyksta Vidurio Rytuose. Todèl, jei tokie pasiūlymai yra viešai aptariami, reikalai darosi nekontroliuojami.

\footnotetext{
${ }^{61}$ Center for Strategic and International Studies, „The Economic Impact of Cybercrime and Cyber Espionage", McAfee, http://www.mcafee.com/us/resources/reports/rp-economic-impact-cybercrime.pdf, 07 2013, p. 3.

${ }^{62}$ Healey J., „Why the U.S. Should Use Cyber Weapons Against Syria“, Defence One, http://www.defenseone.com/technology/2013/08/why-us-should-use-cyber-weapons-against-syria/69776/, 31082013.
} 
Tarptautinè bendruomenė turi stengtis labiau suprasti kibernetinès erdvès pobūdị ir svarbą. Reikalingi nauji kibernetiniai diplomatai ir politikai , kurie vienodai suvoktų tai, kas yra pavojuje, ir pasidalintų šiuo suvokimu. Yra požymių, kad kibernetinè politika pradedama pripažinti nauja saugumo politikos sritimi ${ }^{63}$. Valstybès kibernetinès erdvès veikla yra geriausiai suprantama kaip tarptautinio saugumo, o ne informacijos saugumo klausimas.

Šios problemos negalima perduoti spręsti teisètvarkai, kariuomenei ar žvalgybos tarnyboms. Šie organai yra linkę veikti slapta. Bendradarbiavimas tarp daugelio viešųjų ir privačių sektorių yra pagrindinis faktorius, užtikrinantis saugią kibernetinę erdvę, slaptumas apsunkintų tokị bendradarbiavimą. Ši klausimą turètų skaidriai spręsti civiliai vyriausybių vadovai, nes tik jie gali susidoroti su visais nacionalinio ir tarptautinio saugumo klausimais.

2014 metais bus pažymimas šimtas metų nuo Pirmojo pasaulinio karo pradžios. Istorikai tebekomentuoja ir laužo galvas dèl to, kodèl turejjo įvykti toks baisus karas. Viena iš didžiausių Pirmojo pasaulinio karo staigmenų buvo naujų technologijų panaudojimas, siekiant sukelti mirtiną poveikị. Panaudojus kulkosvaidžius, ipritą, bombardavimą iš oro ir torpedas, buvo prarasta milijonai gyvybių. Siekdami spręsti šiuolaikinius, besikeičiančius iššūkius dẻl valstybių kibernetinèje erdvèje, kurie pateikiami šiame straipsnyje, mes, tikriausiai, galètume pasimokyti iš minèto karo. JAV istorikè Barbara W. Tuchman savo knygoje Rugpjūčio ginklai apie Pirmojo pasaulinio karo pradžią taikliai pastebèjo: „Viena, kas yra būdinga 1914 metams - kaip ir bet kuriam laikotarpiui - kiekvieno, nesvarbu, kurioje pusèje esančio, nusiteikimas nesiruošti sudėtingesnei alternatyvai ir neveikti taip, kaip jie mano esant teisinga." Galbūt, valstybès, kurios dalyvavo tame kare, atsižvelgs ị tai ir elgsis taip, kad užtikrintų, jog kibernetinių ginklų technologija nebūtų panašių tragedijų XXI amžiuje priežastimi?

2013 m. spalis

${ }^{63}$ Choucri N., Cyberpolitics in International Relations, The MIT Press, 2012, p. 238. 